\title{
PENGARUH MODAL ASING, KURS, INFLASI, SUKU BUNGA DAN INDEKS SAHAM TERHADAP KAPITALISASI PASAR MODAL INDONESIA
}

\author{
Pudji Astuty $^{1}$, Almira Rizqia ${ }^{2}$ \\ Dosen Pascasarjana Universitas Borobudur, e-mail : pudji_astuty@borobudur.ac.id \\ Mahasiswa Program Doktor Universitas Borobudur, email : almira.rizqia@gmail.com
}

\begin{abstract}
Tujuan dari riset ini merupakan buat menganalisa Penanaman Modal Asing, Nilai Tukar, Inflasi, Tingkat Suku Bunga, Indeks Saham terhadap Kapitalisasi Pasar Modal Indonesia. Menggunakan Regresi Liner Berganda dengan SPSS. Data Sekunder menggunakan dua jenis periode yakni periode 1990-2019 dan 1990-2020 untuk melihat perbedaan akibat Covid-19. Dari hasil Penelitiannya diketahui Penanaman Modal Asing, Nilai Tukar dan Indeks Saham berpengaruh signifikan positif terhadap Kapitalisasi Pasar Modal Indonesia untuk kedua periode. Sedangkan Suku Bunga hanya berpengaruh negatif di periode 1990-2020 dan Inflasi tidak memberikan pengaruh pada kedua periode tersebut.
\end{abstract}

Kata Kunci: Penanaman Modal Asing, Nilai Tukar Rupiah Dolar, Inflasi, Indeks Saham, Pasar Modal Indonesia

\begin{abstract}
The goal of this research is to examine the impact of Foreign Investment, Exchange Rate, Inflation, Interest Rates, Stock Index on Indonesian Capital Market Capitalization. The research was processed using the SPSS 22 program with multiple linear regression. The data used uses two types of periods, namely the period 1990-2019 and the period 1990-2020 to see the differences due to the Covid-19 Pandemic in 2020. From the results of the research, it is known that Foreign Investment, Exchange Rate and Stock Index have a significant positive effect on Indonesia's Capital Market Capitalization. for both periods. Meanwhile, Interest Rates only had a negative effect in the period 1990-2020 and Inflation had no effect on both periods.
\end{abstract}

Keywords: Foreign Investment, Rupiah Exchange Rate, Inflation, Stock Index, Indonesian Capital Market.

\section{A. PENDAhuluan}

Kemajuan pasar modal di Indonesia akhirakhir ini yang begitu pesat membuat para pelaku pasar modal menyadari bahwa bursa ini dapat memberikan imbal hasil yang besar dan memberikan kontribusi yang luar biasa bagi perbaikan moneter di Indonesia. Banyaknya organisasi yang membuka diri terhadap dunia dan mendaftarkan penawarannya di pasar modal adalah bukti dari kondisi tersebut. Hal ini, baik 
secara langsung maupun implisit, dapat menopang perkembangan industri pasar modal publik ke tingkat yang meyakinkan.

Ada sejumlah instrumen dalam melakukan investasi yang mana masyarakat cenderung populer dengan emas atau properti. Tetapi, hanya sedikit yang mengenal terkait alternatif investasi lewat pasar modal. Pasar modal sebagai instrumen untuk menggalang dana bagi korporasi yang telah Go Public dan Goes International. Dalam menentukan investasi memakai Capital Market atau Pasar Modal ini, tidak sekedar memberi peluang ke masyarakat untuk memperoleh laba. Tetapi juga turut aktif dalam menaikkan keadaan ekonomi negara. Pendapat (Tandelilin, 2011), gunanya pasar modal berlaku seperti Badan perantara( intermediaries) antara pihak yang mempunyai anggaran lebih dengan yang menginginkan pendanaan

Menurut penelitian dari (Ratnaningtyas, 2020) ditemukan bahwa modal asing langsung mempengaruhi signifikan pada indeks harga saham gabungan (IHSG), senada dengan hal tersebut penelitian dari (Almfraji \& Almsafir, 2014) menemukan yakni investasi asing mempengaruhi signifikan positif pada pasar modal dan pasar uang di Malaysia yang pada akhirnya memberikan pengaruh terhadap pertumbuhan ekonomi di Malaysia. Termasuk mendukung penelitian di atas, penelitian dari (Hailemariam \& Guotai, 2014) hasilnya didapat bahwa Foreign Direct Investment( FDI) ataupun modal asing langsung pengaruhi positif serta penting pada perkembangan ekonomi serta pasar modal di Tiongkok. Akan tetapi, tidak sejalan dengan penelitian terdahulu, penelitian dari (Idenyi et al., 2016) mengenai dampak investasi asing di pasar saham Nigeria, didapat hasil bahwa investasi asing tidak mempengaruhi signifikan pada pertumbuhan pasar saham di Nigeria.

Harga saham lazim yang ada di pasar( harga pasar saham) mempunyai maksud berarti untuk industri disebabkan harga berhubungan selaku determinan angka perusahaannya. Angka pasar industri bisa dikenal dari harga saham dikalikan dengan keseluruhan saham yang tersebar. (Tandelilin, 2011). Indikasi pasar modal berkembang menggunakan indikator IHSG, sementara IHSG sangat dipengaruhi kondisi ekonomi nasional maupun global termasuk adanya pandemi covid-19 yang mana memunculkan sentiment positif seperti adanya program vaksinasi maupun sentiment negatif atau ketidakpastian akibat munculnya varian covid).

Beberapa penelitian sebelumnya menunjukkan ada pengaruh dari beberapa indikator makroekonomi terhadap perkembangan pasar modal antara lain seperti PDB, likuiditas pasar modal, modal asing langsung, tingkat inflasi, tingkat tabungan (Azeez \& Obalade, 2018) Pengaruh nilai tukar mata uang asing terhadap perkembangan pasar modal (Sichoongwe, 2016), (Adebowale \& Akosile, 2018) dan (Obura \& Anyango, 2016).

Perusahaan domestik dengan aktivitas operasional yang sudah global akan dipengaruhi langsung dari fluktuasi nilai tukar bersangkutan. Namun, berbeda dengan perusahaan domestik yang aktivitas operasionalnya di domestik juga, maka tidak akan dipengaruhi langsung dari fluktuasi nilai tukar uangnya. Sehingga, harga saham perusahaan dan pasar modal akan terjadi reaksi atas berubahnya nilai tukar uang bersangkutan. Perubahan harga saham akan memberi pengaruh perusahaan dalam menyesuaikan portofolio perusahaannya.

Beberapa penelitian mengenai pengaruh nilai tukar mata uang asing pada perkembangan pasar modal antara lain, menurut penelitian (Sichoongwe, 2016) yang meneliti mengenai dampak nilai tukar mata uang pada pasar modal di Zambia dihasilkan bahwa nilai tukar mata uang asing mempengaruhi negatif pada pasar modal di Zambia. Sementara itu pada penelitian (Adebowale \& Akosile, 2018) ditemukan bahwa 
tingkat suku bunga memberikan pengaruh negatif terhadap pasar modal sedangkan nilai tukar mata uang asing memberikan pengaruh positif terhadap pasar modal di Nigeria. Sejalan dengan penelitian dari (Obura \& Anyango, 2016) yakni tingkat suku bunga dan nilai tukar mata uang asing mempengaruhi pasar modal.

Selain nilai tukar mata uang asing, indikator makroekonomi lainnya adalah inflasi. Inflasi merupakan kenaikan harga barang dan jasa yang memiliki pengaruh yang meluas, begitu pula terhadap harga saham di pasar modal. Tingkat inflasi umumnya bisa menurunkan daya beli tiap unit mata uang. Indeks Harga Konsumen (consumer price index) sebagai salah satu indikator inflasi merupakan ukuran total biaya atas barang dan jasa yang dibeli konsumennya (Mankiw, 2011)

Beberapa penelitian sebelumnya mengenai dampak inflasi terhadap perkembangan pasar modal ada dari (Qamri et al., 2015) yang meneliti mengenai dampak inflasi terhadap harga saham di Pakistan, dalam penelitiannya menemukan bahwa ada hubungan negatif antara inflasi dengan harga saham di Pakistan. Namun, penelitian tersebut berbanding terbalik dengan hasil penelitian dari (Al-Tarawneh \& Al-Assaf, 2018), yang meneliti hubungan inflasi dengan pasar saham di negara berkembang, didapatkan hasil bahwa inflasi memberikan pengaruh positif terhadap perkembangan pasar modal di negara berkembang.

Sewaktu ancaman inflasinya naik, bank sentral sebagai pihak yang mempunyai otoritas paling tinggi dalam menentukan kebijakan moneter akan berupaya melakukan pengendalian dengan meningkatkan suku bunga. Naiknya suku bunga diharap bisa merangsang investor sehingga tergerak untuk berinvestasi tunai dalam instrumen pendapatan tetap, sehingga mengurangi kelebihan likuiditas dari sistem. Konsepnya, bila likuiditasnya rendah maka akan terjadi permintaaan spekulatif untuk produk ekonomi sehingga bisa memperlamban naiknya harga umum

Beberapa penelitian sebelumnya mengenai pengaruh suku bunga terhadap perkembangan pasar modal adalah pada penelitian (Adebowale \& Akosile, 2018) ditemukan yakni taraf suku bunga mempengaruhi negatif pada pasar modal, akan tetapi berkebalikan dari penelitian tersebut ada penelitian dari (Ali \& Fei, 2016) yang menyatakan bahwa tingkat suku bunga mempengaruhi positif pada pasar modal dan perkembangan ekonomi di Malaysia.

Bersumber pada pemaparan kerangka di atas hingga tujuan dari riset ini merupakan buat menganalisa pengaruh Penanaman Modal Asing, Nilai Tukar, Inflasi, Tingkat Suku Bunga dan Indeks Pasar Saham terhadap Kapitalisasi Pasar Modal Indonesia.

Pasar modal adalah komponen penting serta tolak ukur kemajuan perekonomian sebuah negara. tiap negara pastinya mempunyai pasar modal kecuali untuk negara tertinggal serta membutuhkan pembenahan dalam pemerintahannya (Sunariyah, 2013). Dari penjabaran di atas bahwa banyak sekali indikator yang dapat mempengaruhi perkembangan pasar modal yaitu investasi asing langsung, harga indeks saham, volume transaksi, frekuensi transaksi, kegiatan eksport dan import, kegiatan perbankan, tingkat suku bunga, nilai tukar, tingkat menabung, dan lain sebagainya.

Tetapi pada studi ini, pengarang berupaya merestriksi pada kelima faktor independent yang memiliki dasar lumayan kokoh buat pengaruhi kemajuan pasar modal di Indonesia antara lain elastis pemodalan asing langsung yang ditengarai dari jatah kepemilikan pemodalan asing yang senantiasa berkuasa di dalam pasar modal Indonesia. variabel kedua adalah nilai tukar mata uang asing rupiah ke US Dollar dikarenakan seiring dengan besarnya porsi kepemilikan investasi asing langsung di 
pasar modal Indonesia, maka nilai tukar mata uang asing seharusnya turut berperan dalam meningkatkan porsi kepemilikan asing tersebut.

Variabel ketiga adalah tingkat inflasi, walau memiliki hubungan tidak langsung terhadap harga saham akan tetapi, pengaruh inflasi terhadap kinerja perusahaan dan daya beli masyarakat dapat memberikan dampak terhadap pasar modal melalui keputusan investasi yang dilakukan masyarakat di tengah inflasi. Variabel keempat adalah tingkat suku bunga, berawal dari tingkal inflasi apabila berada pada tingkat yang membahayakan atau sulit dikendalikan, maka Bank Indonesia selaku pemegang otoritas kebijakan moneter berhak menetapkan tingkat suku bunga untuk menahan laju tingkat inflasi tersebut.

Variabel kelima adalah Indeks Pasar Saham yang diproksikan dengan IHSG (Indeks Harga Saham Gabungan), untuk melihat sejauh mana performansi IHSG dalam menyumbang ke peningkatan Kapitalisasi Pasar Modal Indonesia.

Bersumber pada pemaparan permasalahan di atas hingga terbuat kumpulan permasalahan:

1. Apakah terdapat pengaruh Penanaman Modal Asing terhadap Kapitalisasi Pasar Modal Indonesia ?

2.Apakah terdapat pengaruh Nilai Tukar terhadap Kapitalisasi Pasar Modal Indonesia?

3.Apakah terdapat pengaruh Inflasi terhadap Kapitalisasi Pasar Modal Indonesia ?

4.Apakah terdapat pengaruh Tingkat Suku Bunga terhadap Kapitalisasi Pasar Modal Indonesia?

5.Apakah terdapat pengaruh Indeks Pasar Saham terhadap Kapitalisasi Pasar Modal Indonesia?

\section{B. TINJAUAN PUSTAKA}

Perkembangan Pasar Modal Indonesia

Kapasitas pasar modal dalam suatu bangsa dapat dibedakan berdasarkan lima sudut pandang (Sunariyah, 2013) khususnya:
1. Menjadi metode untuk melakukan pertukaran antara pembeli dan penjual dalam menentukan biaya penawaran dan keuntungan yang dipertukarkan. Pasar modal dapat bekerja sama dengan bursa sehingga kedua pelaku dapat melakukan pertukaran tanpa harus bertatap muka.

2. Pasar modal membuka peluang bagi para pendukung keuangan dalam menentukan return yang ideal. Pasar modal membuka keadaan yang menjanjikan bagi penjamin untuk memuaskan keinginan investor, strategi keuntungan dan tingkat kesehatan biaya perlindungan yang pada umumnya akan menjadi ciri khas.

3. Pasar modal membuka keadaan yang menjanjikan bagi para pendukung keuangan untuk bertukar penawaran atau keuntungan yang berbeda.

4. Pasar modal membuka keadaan yang menjanjikan bagi masyarakat luas untuk mengambil bagian dalam perbaikan perekonomian.

5. Pasar modal mengurangi biaya pertukaran data dan proteksi. Pasar modal memberikan total kebutuhan data kepada para penyandang dana yang jika harus diteliti sendiri bisa membutuhkan biaya yang sangat besar. Perkembangan pasar modal di Indonesia dimulai dari tahun 1912 hingga saat ini yang menjadi tempat bursa proteksi, khususnya dari BEJ (Bursa Efek Jakarta) yang belum lama ini telah berubah menjadi BEI. Kerangka kerja pertukaran saat ini di BEI menggunakan kerangka pasar yang digerakkan oleh permintaan dan kerangka kerja tanpa henti. Kerangka kerja pasar yang didorong permintaan bekerja dengan pertukaran perlindungan melalui pedagang, sedangkan kerangka kerja penjualan nonstop bertukar di mana biaya diperoleh dari pertukaran oleh pasar organik dari pendukung keuangan.

Foreign Direct Investment

Ialah bagian dari pemodalan asing yang mana pemodalan asing dibagi jadi Pemodalan 
Asing Langsung dan Pemodalan Portfolio Asing. Investasi Asing Langsung ialah modal yang dipunyai serta dikelola pihak asing sedangkan Investasi Portfolio Asing adalah investasi yang didanai dengan uang asing namun dikelolaoleh pihak domestik (Mankiw, 2011) Sedangkan menurut (Jhingan, 2012) penanaman modal asing (PMA) maksudnya industri dari negeri asal modal dengan de facto atau de jure melaksanakan pengawasan dari peninggalan yang diinvestasikan di negeri akseptor;penciptaan sebuah perusahaan menggunakan kepemilikan mayoritas saham; penciptaan sebuah perusahaan yang didanai perusahaan penanam modal maupun menempatkan aset tetap di negara penerima

Inflasi

Inflasi merupakan penambahan dalam semua tingkat harga. Lawan dari inflasi yaitu deflasi yang merupakan pelemahan terhadap semua tingkat harga. biasanya, para pakar ekonomi sebagai contoh (Hutabarat, 2018) perubahan logaritma natural dari harga digunakan untuk menghitung inflasi. Indeks Harga Konsumen merupakan ukuran semua biaya dari barang serta jasa yang konsumen beli (Mankiw, 2011). Inflasi bisa juga dihitung dengan memakai indeks harga produsen maupun yang dinamakan indeks harga perdagangan besar yakni dengan mengetahui prosentase perubahan berdasarkan indeks harga perdangangan besar. Daftar nilai diskon atau sering disebut sebagai daftar nilai pembuat adalah proporsi dari banyak relatif biaya barang dan administrasi yang diproduksi oleh pembuat (Mandala Manurung, 2014)

\section{Tingkat Suku Bunga}

Biaya pembiayaan dipisahkan menjadi biaya pinjaman nyata dan asli. Biaya pembiayaan yang tidak fokus pada tingkat ekspansi (menunjukkan ukuran uang tunai yang berkembang dalam dana investasi) adalah pentingnya biaya pinjaman nyata. Sedangkan biaya pembiayaan yang telah mempertimbangkan tingkat ekspansi (mencerminkan kenaikan atau penurunan daya beli dana investasi) dikenal sebagai biaya pinjaman asli. Biaya pinjaman asli adalah biaya pembiayaan nyata dikurangi tingkat ekspansi (Mankiw, 2011) .

\section{Indeks Harga Saham Gabungan}

Harga saham lazim yang terjalin di pasar( harga pasar saham) sedemikian itu berarti untuk industri karena harga itu jadi determinan besaran angka industri. angka industri bisa diukur dengan hasil multiplikasi harga saham dengan jumlah saham yang tersebar. (Tandelilin, 2011).Indikasi pasar modal berkembang menggunakan indikator IHSG.

Beranjak dari latar belakang yang telah diuraikan, bisa dirumuskan hipotesis seperti di bawah ini:

1. Hipotesis 1 : Penanaman Modal Asing Langsung mempengaruhi dengan signifikan dan positif terhadap Pengembangan Pasar Modal Indonesia

2. Hipotesis 2 : Nilai Tukar mempengaruhi dengan signifikan dan positif terhadap Pengembangan Pasar Modal Indonesia

3. Hipotesis 3 : Inflasi mempengaruhi dengan signifikan dan positif terhadap Pengembangan Pasar Modal Indonesia

4. Hipotesis 4 : Tingkat Suku Bunga mempengaruhi dengan signifikan dan negatif terhadap Pengembangan Pasar Modal Indonesia

5. Hipotesis 5 : Indeks Pasar Saham mempengaruhi dengan signifikan dan positif terhadap Pengembangan Pasar Modal Indonesia

\section{METODE}

Penelitian: Jenis penelitian untuk eksplorasi grafis yang desainnya untuk menggambarkan, meringkas berbagai peristiwa atau berbagai faktor yang ada secara lokal yang menjadi objek eksplorasi (Bungin, 2013) Konfigurasi penelitian investigasi kontekstual adalah pemeriksaan eksploratif dan merupakan kunci dalam mencari terjemahan spekulasi individu sehubungan dengan faktor-faktor sosial. 
Hubungan variabel dalam pemeriksaan persahabatan pada umumnya diamati sebagai faktor otonom, faktor tengah dan faktor lingkungan.

Tipe Informasi serta Prosedur Pengumpulan Informasi: Tipe informasi memakai informasi sekunder yang bersumber dari bermacam basis antara lain Bank Indonesia, Pasar uang Efek Indonesia serta World Bank. Informasi yang dipakai memakai informasi time series sepanjang 30 tahun ialah tahun 1990- 2020. Untuk mengetahui adanya pengaruh Covid-19 maka regresi dilakukan dua periode yakni periode sebelum Pandemi Covid-19 tahun 19902019 dan 1990 - 2020.

Pengumpulan data dengan studi kepustakaan (library research) dimana peneliti mencari informasinya dengan cara mengumpulkan berbagai data yang didapatkan dari buku, perusahaan, notulen, dan referensi yang berkaitan dengan tema yang dikaji.

Persamaan: Penelitian ini dapat dirumuskan dengan :

Kapitalisasi Pasar Modal $=\mathrm{Y}$, guna faktor terikat merupakan faktor antara yang memperoleh akibat dengan cara simultan oleh faktor- faktor determinan, hingga bentuk modelnya jadi:

$$
Y=f\left(X^{1}, X^{2}, X^{3}, X^{4}, X^{5}\right)
$$

Dengan :

$\beta 0 \ldots . . \mathrm{n}=$ Konstanta Persamaan $1 \mathrm{~s} / \mathrm{d} \mathrm{n}$

$€ 1 \ldots . . \mathrm{n}=$ Standar Error persamaan $1 \mathrm{~s} / \mathrm{d} \mathrm{n}$

$\mathrm{Y}=$ Kapitalisasi Pasar Modal

$\mathrm{X}^{1}=$ Foreign Direct Investment (FDI)

$\mathrm{X}^{2}=$ Nilai Tukar Rupiah ke Dollar Amerika

$\mathrm{X}^{3}=$ Inflasi

$\mathrm{X}^{4}=$ Suku Bunga

$\mathrm{X}^{5}=$ Indeks

\section{HASIL DAN PEMBAHASAN}

Analisa Deskriptif

Data deskriptif kelima variabel selama periode 1990-2020 adalah sebagai berikut :
Untuk Penanaman Modal Asing memiliki ratarata pertumbuhan sebesar $18 \%$, artinya seiring dengan kestabilan ekonomi Indonesia mengindikasikan ada peningkatan pertumbuhan investasi asing. Nilai Tukar Rupiah memiliki rata-rata pertumbuhan sebesar $15,94 \%$, artinya seiring dengan peningkatan investasi asing ke Indonesia, juga diiringi dengan peningkatan nilai Tukar mata uang asing Dolar Amerika terhadap Rupiah.

Inflasi memiliki rata-rata pertumbuhan 29\%, artinya adanya kenaikan harga konsumen indeks seiring dengan peningkatkan konsumsi masyarakat Indonesia. Tingkat Suku Bunga memiliki rata-rata perumbuhan $-0,5 \%$, artinya ada penurunan tingkat suku bunga seiring adanya kebijakan Bank Indonesia untuk menggenjot perputaran uang untuk produktivitas dan menjaga inflasi, Indeks Harga Saham Gabungan Indonesia memiliki rata-rata pertumbuhan $15,56 \%$, artinya ada peningkatan seiring dengan semakin meningkatnya investasi di Pasar Modal Indonesia.

\section{Uji Asumsi Klasik}

Percobaan taksiran klasik yang dicoba antara lain Percobaan Multikolinearitas dengan memandang angka VIF $<10$ serta angka tolerance 0,1 , dimana seluruh peubah tidak alami pertanda multikolinearitas. Uji Normalitas menggunakan Kolmogorov Smirnov Test dan didapat nilai probabilitas 0,996>0,05. Percobaan Autokorelasi memakai Durbin Watson dengan angka DW 1, 017 diantara- 2 serta+2 yang maksudnya tidak terjalin autokorelasi. Uji Hesterokedastisitas menggunakan uji Rank Spearman dengan nilai probabilitas $>0,05$ sehingga lolos uji heteroskedastisitas.

\section{Uji Regresi}

\section{1) Uji Parsial}

Dari uji regresi menggunakan SPSS untuk dua periode 1990-2019 dan 1990-2020 didapat hasil sebagai berikut untuk Uji Parsial : 
Tabel 1.

Hasil Regresi 1990-2019

\begin{tabular}{|c|c|c|c|}
\hline $\begin{array}{c}\text { Variabe } \\
\mathbf{l}\end{array}$ & $\begin{array}{c}\text { Unstandardize } \\
\mathbf{d} \text { Coefficients } \\
\mathbf{B}\end{array}$ & $\mathbf{t}$ & Sig. \\
\hline $\begin{array}{c}\text { Constan } \\
t\end{array}$ & 187407.807 & 1.51 & 0.144 \\
\hline $\mathrm{X} 1$ & 16.234 & 3.447 & 0.002 \\
\hline $\mathrm{X} 2$ & 11.358 & 2.45 & 0.022 \\
\hline $\mathrm{X} 3$ & -1719.791 & -1.382 & 0.18 \\
\hline $\mathrm{X} 4$ & -11042.79 & -1.959 & 0.062 \\
\hline $\mathrm{X} 5$ & 36.007 & 3.187 & 0.004 \\
\hline
\end{tabular}

Sumber : SPSS, diolah, 2021

Dari Model Regresi didapat persamaan : $\mathrm{Y}=$ $187407.807+16.234 \mathrm{X}^{1}+11.358 \mathrm{X}^{2}-$ $1719.791 X^{3}-11042.79 X^{4}+36.007 X^{5}$.

Berdasarkan tabel di atas maka didapat pengaruh FDI terhadap Kapitalisasi Pasar Modal diperoleh t hitung sebesar 3,447 dan pvalue $0,002<0,05$ dengan begitu pengaruh tersebut positif signifikan. Pengaruh Nilai Tukar terhadap Kapitalisasi Pasar Modal didapatkan t hitung sebesar 2,450 dan p-value 0,022<0,05 sehingga pengaruh tersebut positif tidak signifikan.

Pengaruh Inflasi terhadap Kapitalisasi Pasar Modal didapatkan $t$ hitung sebesar -1,382 dan pvalue $0,180>0,05$ artinya pengaruh tersebut positif tidak signifikan. Pengaruh Tingkat suku bunga terhadap Kapitalisasi Pasar Modal didapatkan t hitung sebesar -1,959 dan p-value $0,062>0,05$ artinya pengaruh tersebut positif tidak signifikan.
Tabel 2.

Hasil Regresi 1990-2020

\begin{tabular}{|c|c|c|c|}
\hline $\begin{array}{l}\text { Vari } \\
\text { abel }\end{array}$ & $\begin{array}{c}\text { Unstandar } \\
\text { dized } \\
\text { Coefficients } \\
\text { B }\end{array}$ & $\mathbf{t}$ & Sig. \\
\hline$C$ & 216996.676 & 1.846 & 0.077 \\
\hline $\mathrm{X} 1$ & 15.396 & 3.379 & 0.002 \\
\hline $\mathrm{X} 2$ & 10.979 & 2.399 & 0.024 \\
\hline $\mathrm{X} 3$ & -1703.587 & -1.38 & 0.18 \\
\hline $\mathrm{X} 4$ & -12353.813 & $\begin{array}{c}- \\
2.309\end{array}$ & 0.029 \\
\hline $\mathrm{X} 5$ & 32.71 & 3.136 & 0.004 \\
\hline
\end{tabular}

Sumber : SPSS, diolah, 2021

Dari Model Regresi didapat persamaan : $\mathrm{Y}=$ $216996.676+15.396 X^{1}+10.979 X^{2}-1703.587$ $X^{3}-12353.813 X^{4}+32.71 X^{5}$.

Berdasarkan tabel di atas maka Pengaruh FDI terhadap Kapitalisasi Pasar Modal didapatkan thitung sebesar 3,379 dan p-value $0,002<0,05$ artinya pengaruh tersebut positif signifikan. Pengaruh Nilai Tukar terhadap Kapitalisasi Pasar Modal didapatkan thitung sebesar 2,399 dan p-value 0,024<0,05 artinya pengaruh tersebut positif signifikan. Pengaruh Inflasi terhadap Kapitalisasi Pasar Modal didapatkan thitung sebesar -1,380 dan p-value $0,180>0,05$ artinya pengaruh tersebut positif tidak signifikan.

Pengaruh Tingkat suku bunga terhadap Kapitalisasi Pasar Modal diperoleh $\mathrm{t}$ hitung sebesar -2,309 dan p-value 0,029<0,05 artinya pengaruh tersebut negative signifikan.

Pengaruh Indeks pasar saham terhadap Kapitalisasi Pasar Modal didapatkan thitung sebesar 3,136 dan p-value $0,004<0,05$ artinya pengaruh tersebut positif signifikan

\section{2) Uji F}

Hasil uji F untuk periode 1990-2019 didapatkan nilai $\mathrm{p}$-value $0,000<0,05$ sehingga artinya secara bersamaan variabel Penanaman Modal Asing, Nilai Tukar, Inflasi, Tingkat Suku 
Bunga dan Indeks Pasar Saham berpengaruh terhadap Kapitalisasi Pasar Modal Indonesia.

Hasil uji F untuk periode 1990-2020 didapatkan nilai $\mathrm{p}$-value $0,000<0,05$ sehingga artinya secara bersamaan variabel Penanaman Modal Asing, Nilai Tukar, Inflasi, Tingkat Suku Bunga dan Indeks Pasar Saham berpengaruh terhadap Kapitalisasi Pasar Modal Indonesia.

\section{3) Uji R-Squared}

Hasil Adjusted R-Squared untuk periode 1990-2019 sebesar 0,894, artinya variabel Penanaman Modal Asing, Nilai Tukar, Inflasi, Tingkat Suku Bunga dan Indeks Pasar Saham berpengaruh terhadap Kapitalisasi Pasar Modal Indonesia sebesar 89,4 persen.

Hasil Adjusted R-Squared untuk periode 19902020 sebesar 0,897, artinya variabel Penanaman Modal Asing, Nilai Tukar, Inflasi, Tingkat Suku Bunga dan Indeks Pasar Saham berpengaruh terhadap Kapitalisasi Pasar Modal Indonesia sebesar 89,7 persen.

\section{E. Diskusi}

Hasil dari riset dimana Penanaman Modal Asing membagikan akibat positif serta bermakna kepada Pasar Modal searah dengan riset sebelumnya antara lain riset dari (Ali \& Fei, 2016) didapatkan hasil bahwa investasi asing langsung memberikan dampak positif signifikan terhadap pasar modal dan pertumbuhan ekonomi. Penelitian (Ratnaningtyas, 2020) ditemukan bahwa modal asing langsung memberikan pengaruh signifikan terhadap IHSG, senada dengan hal tersebut penelitian dari (Almfraji \& Almsafir, 2014) menemukan jika penanaman modal asing mempengarhi secara signifikan positif terhadap pasar modal dan pasar uang di Malaysia yang pada akhirnya memberikan pengaruh terhadap pertumbuhan ekonomi di Malaysia

Riset Angka Tukar Mata Uang mempengaruhi positif serta bermakna pula dibantu oleh riset sebelumnya ialah (Narayan et al., 2020) hasil riset membuktikan ada ikatan kalau angka tukar Yen yang terus menjadi terdepresiasi kepada Dollar AS menimbulkan kenaikan kepada Return Saham sepanjang wabah Covid- 19. Kemudian pada penelitian (Adebowale \& Akosile, 2018) ditemukan jika nilai tukar mata uang asing memberikan pengaruh positif terhadap pasar modal di Nigeria. Sejalan dengan penelitian dari (Obura \& Anyango, 2016) bahwa nilai tukar mata uang asing memberikan pengaruh positif terhadap pasar modal.

Hasil riset inflasi tidak memberikan pengaruh sejalan dengan beberapa penelitian berikut yakni (Akoko \& State, 2021) menemukan bahwa tingkat inflasi tidak memberikan pengaruh terhadap kapitalisasi pasar modal di Nigeria dari tahun 1986-2017. (Omodero, 2020) menemukan bahwa tingkat inflasi tidak memberikan pengaruh yang signifikan terharap kinerja kapitalisasi pasar modal di Nigeria untuk periode 1998-2018 menggunakan data dari World Bank. (Megaravalli \& Sampagnaro, 2018) mendapatkan kalau inflasi tidak mempunyai akibat yang penting dan minus kepada pasar modal pada 3 negeri Asia ialah India, Cina serta Jepang sepanjang rentang waktu Januari 2008 serta November 2016

Pengaruh signifikannya tingkat suku bunga di Indonesia pada saat pandemi Covid-19, sejalan dengan riset yang dilakukan oleh (Gao et al., 2021) menemukan bahwa di Amerika dalam menangani volatilitas Pasar Modal di tengah pandemi Covid-19,The Fed/Bank Sentral memberlakukan penurunan suku bunga sehingga pasar modal dapat kembali bangkit.

Sementara itu di Indonesia juga melakukan hal serupa dimana Bank Indonesia melakukan penurunan suku bunga ke level terendah sepanjang sejarah sejak Maret 2020 dimana pandemi Covid-19 diumumkan ke Indonesia. Serupa dikenal, BI terakhir kali merendahkan suku bunga rujukan pada 19 November 2020 
kemudian dari $4 \%$ jadi 3, 75\%. Selama 2020, BI sudah memotong suku bunga rujukan 5 kali, ataupun sebesar 125 dasar nilai( bps).

Pengaruh indeks pasar saham terhadap kapitalisasi pasar modal didukung oleh penelitan (Lee et al., 2012) pada Indeks pasar saham Taiwan ke Pasar Saham Honkong dan (Josphat \& Kipkirong, 2012) harga saham memberikan pengaruh positif signifkan ke pasar modal Kenya.

\section{Ucapan Terima Kasih}

Tuturan terima kasih lebih- lebih tertuju pada para dosen serta karyawan Universitas Borobudur yang sudah membagikan dorongan buat kelancaran riset ini.

\section{F. KESIMPULAN}

Kesimpulan yang diperoleh adalah pada kedua periode yakni 1990-2019 dan 1990-2020 variabel Penanaman Modal Asing, Nilai Tukar dan Indeks Pasar Saham sama-sama memberikan pengaruh signifikan dan positif terhadap Kapitalisasi Pasar Modal. Sementara pada tingkat Suku Bunga hanya memberikan pengaruh signifikan negatif pada periode 19902020 dimana dipengaruhi kebijakan Bank Indonesia pada masa Pandemi Covid-19 yang menurunkan tingkat Suku Bunga sepanjang sejarah Indonesia. Inflasi adalah variabel yang tidak memberikan pengaruh di kedua periode terhadap Kapitalisasi Pasar Modal Indonesia.

\section{Saran}

Saran yang dapat disampaikan adalah supaya Pemerintah dapat lebih memperhatikan indikator makroekonomi karena mempunyai dampak terhadap perkembangan Pasar Modal Indonesia, antara lain kemudahan investasi asing, menjaga fluktuasi nilai Tukar Rupiah terhadap Dolar, menjaga stabilitas tingkat suku bunga dan memberikan sosialisasi seluasluasnya kepada masyarakat untuk berinvestai melalui Pasar Modal Indonesia

\section{DAFTAR PUSTAKA}

Adebowale, E. A., \& Akosile, A. I. (2018). Interest rate, foreign exchange rate, and stock market development in Nigeria. Binus Business Review, 9(3), 247-253.

Akoko, A., \& State, O. (2021). CAPITAL MARKET AND INFLATIONARY PRESSURE IN. 2014, 2017-2022.

Al-Tarawneh, A., \& Al-Assaf, G. (2018). Macroeconomic Drivers of Stock Market Development: Evidence From Jordan. International Journal of Financial Research, 9(3), 117-124.

Ali, M. A., \& Fei, Y. S. (2016). Impact of Malaysia's capital market and determinants on economic growth. The Journal of Asian Finance, Economics, and Business, 3(2), 5-11.

Almfraji, M. A., \& Almsafir, M. K. (2014). Foreign direct investment and economic growth literature review from 1994 to 2012. Procedia-Social and Behavioral Sciences, 129, 206-213.

Azeez, B. A., \& Obalade, A. A. (2018). Macroeconomic determinants of stock market development in Nigeria:(19812017. Acta Universitatis Danubius. Economica, 15(1).

Bungin, B. (2013). Metode penelitian sosial \& ekonomi: format-format kuantitatif dan kualitatif untuk studi sosiologi, kebijakan, publik, komunikasi, manajemen, dan pemasara edisi pertama. kencana prenada media group.

Gao, X., Ren, Y., \& Umar, M. (2021). To what extent does COVID-19 drive stock market volatility? A comparison between the US and China. Economic ResearchEkonomska Istraživanja.

Hailemariam, A., \& Guotai, C. (2014). Stock market development and economic growth: Empirical evidence for emerging market economies. International Journal of Economics, Finance and Management Sciences, 2(2), 171-181.

Hutabarat, R. (2018). Transaksi Ekspor Impor. 
Erlangga.

Idenyi, O. S., Ifeyinwa, A. C., Obinna, N. J., \& Promise, E. A. (2016). Impact of foreign direct investment on stock market growth in Nigeria. Asian Research Journal of Arts \& Social Sciences, 1-14.

Jhingan, M. L. (2012). Ekonomi Pembangunan dan Perencanaan. Rajawali Press.

Josphat, K. K., \& Kipkirong, T. D. (2012). Macroeconomic determinants of stock market development in emerging markets. Evidence from Kenya.

Lee, C., Shie, F. S., \& Chang, C. Y. (2012). How close a relationship does a capital market have with other such markets? The case of Taiwan from the Asian financial crisis. Pacific Basin Finance Journal, 20(3), 349-362. https://doi.org/10.1016/j.pacfin.2011.11.00 3

Mandala Manurung, P. R. (2014). Teori Ekonomi Makro. Fakultas Ekonomi Universitas Indonesia.

Mankiw, Ng. (2011). Pengantar Ekonomi Makro. jakarta:Erlangga

Megaravalli, A. V., \& Sampagnaro, G. (2018). Macroeconomic indicators and their impact on stock markets in ASIAN 3: A pooled mean group approach. Cogent Economics and Finance, 6(1). https://doi.org/10.1080/23322039.2018.14 32450

Narayan, P. K., Devpura, N., \& Wang, H. (2020). Japanese currency and stock market - What happened during the COVID-19 pandemic? Economic Analysis and Policy, 68, 191-198.

Obura, J. M., \& Anyango, C. (2016). Moderating effect of interest rates on relationship between foreign exchange rate fluctuation and performance of Nairobi securities exchange market. Universal Journal of Accounting and Finance, 4(2), 27-34.

Omodero, C. O. (2020). Capital market determinants and market capitalization in
Nigeria. International Journal of Financial Research, 11(1), 462-473. https://doi.org/10.5430/ijfr.v11n1p462

Qamri, G. M., Haq, M. A. U., \& Akram, F. (2015). The impact of inflation on stock prices: Evidence from Pakistan. Microeconomics and Macroeconomics, 3(4), 83-88.

Ratnaningtyas, H. (2020). Pengaruh Foreign Direct Investment, Inflasi, Bi Rate Dan Nilai Kurs Rupiah Terhadap Indeks Harga Saham Gabungan Indeks Di Bursa Efek Indonesia Periode Tahun 2010-2018. Mabiska Journal, 5, 1-15.

Sichoongwe, K. (2016). Effects of exchange rate volatility on the stock market: The Zambian experience. Journal of Economics and Sustainable Development, 7(4).

Sunariyah. (2013). Pengantar Pengetahuan Pasar Modal (Edisi 6). UPP STIM YKPN.

Tandelilin, E. (2011). Portofolio dan Investasi: Teori dan Aplikasi. Edisi 1. Kanisius. 